\title{
最近の歯学
}

\section{3. 予防歯科}

国民の歯磨きの状況一平成 5 年保健福祉動向調查の結果から一

東京医科歯科大学歯学部予防歯科学講座 岡田昭五郎

平成 5 年 6 月に実施された保健福祉動向調査（歯科 保健）では，国民の歯磨きの状況について詳しく調査 されている。この調査は厚生省が全国 300 地区の満 15 歳以上の世帯員約 33,000 人に対して行った結果で, 1 日の歯磨き回数, 通常の歯ブラシでどのように磨いて いるか，何分ぐらい磨いているか，歯の磨き方の指導 を受けたことがあるかなどが調査されている。

毎日磨く人のなかでは 1 日 2 回磨く人が $45 \%, 3$ 回 以上磨く人が約 $16 \%$ である。女性では約 $70 \%$ が 2 回以 上磨くと答えているが, 夜寝る前と朝食後に磨く人の 率が高い。男性で 2 回以上磨く人は約 $50 \%$ で, 朝起き た時に磨く人の率が最も高く, 次いで夜寝る前に磨く 人が高い率であった。

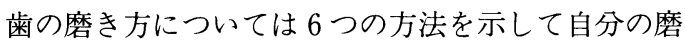
き方にあてはまる方法すべてに丸をつける(複数回答) ことでその人の磨き方を調查している。結果は表に示 すとおりで，半数の人は歯ブラシを上下に回転させる ように磨くと答えている。これは過去に学校での歯磨 き指導が回転法を中心とした指導であったことを考之 ると納得できるところである。小さく横に動かして磨 くという人は約 $30 \%$ で女性に多い傾向がみられる。ま た，歯ブラシを歯と歯ぐきの間にあてて細かく振動さ せて磨くという人も女性に多い。これに比べて男性で は大きく横に動かして磨く，力を入れて磨くという人 が多い。

過去 1 年間に歯磨き指導を受けたという人は男性 $11.7 \%$ ，女性 $14.3 \%$, 男女の総数で $13.0 \%$ である。図 に示すように指導を受けた人では小さく動かして磨
く，歯ブラシを歯と歯ぐきの間にあてて細かく振動さ せて磨く人の率が高く, 大きく横に動かして磨く人や, 力を入れて磨くという人の率が低い傾向がみられる。 また，歯磨き指導を受けた人では歯磨きの時間も長い 傾向がみられている。近年歯科診療所などでは, バス 法やスクラビング法で隅々まできれいに磨く指導が行 われているが, これらの結果はその指導の効果が現れ てきていると考えてよかろう。

\section{文献}

1）厚生省大臣官房統計情報部編：平成 5 年保健福祉 動向調査 (歯科保健). 東京, 1994, 財団法人厚生 統計協会.

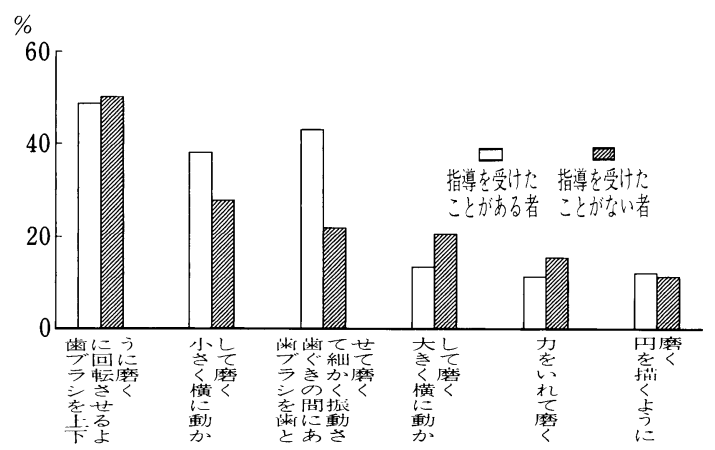

図＼cjkstart歯の磨き方 [毎日歯を磨く者, 総数 (男女計), 歯 磨き指導の有無別, 複数回答]

複数回答なので指導を受けたことのある者, ない者 それぞれの合計は $100 \%$ にならない

表 歯の磨き方 [毎日歯を磨く者, 複数回答]

\begin{tabular}{|c|c|c|c|c|c|c|c|}
\hline 性 & $\begin{array}{l}\text { 歯ブラシを回転させ } \\
\text { るように磨く }\end{array}$ & $\begin{array}{l}\text { 小さく横に動 } \\
\text { かして磨く }\end{array}$ & $\begin{array}{l}\text { 歯プラシを歯と歯くきき } \\
\text { の間にあて細加振動 } \\
\text { させて磨く }\end{array}$ & $\begin{array}{l}\text { 大きく横に動 } \\
\text { かして磨く }\end{array}$ & 力をいれて磨 & $\begin{array}{l}\text { 円を描くよう } \\
\text { に磨く }\end{array}$ & その他 \\
\hline 男 & $47.0 \%$ & $24.7 \%$ & $19.5 \%$ & $25.3 \%$ & $20.7 \%$ & $10.3 \%$ & $4.5 \%$ \\
\hline 女 & 52.7 & 33.6 & 29.9 & 14.9 & 10.0 & 12.7 & 4.8 \\
\hline 計 & 50.0 & 29.4 & 25.0 & 19.8 & 15.0 & 11.6 & 4.7 \\
\hline
\end{tabular}

複数の方法で磨く人もいる（複数回答）ので，男女それぞれの合計は $100 \%$ 